\title{
Kedudukan Ilmu Hukum Dalam Perspektif Filsafat Ilmu Pengetahuan
}

\author{
Oleh : \\ ABDUL HALIM BARKATULLAH
}

\begin{abstract}
Phylosophy through its branchs could be used to analyze a problems deeply untill we found the essence of the problem. It brings a person to have philosophical thinking untill he draw integrated and focused conclusion. To analyze the position of legal science in the science, so it needs philosophical thinking. It will brings a legal development which not only able to reached current legal problems in society, but also future legal problems. Legal science development decided by the development of onthology, ephistimology, and acsiology aspects of legal science.
\end{abstract}

